\title{
The cytogenetics and evolution of forage legumes from Rio Grande do Sul: a review
}

\author{
Maria Teresa Schifino-Wittmann \\ Departamento de Plantas Forrageiras e Agrometeorologia, Faculdade de Agronomia, Universidade Federal do Rio Grande do Sul, \\ Caixa Postal 776, 91501-970 Porto Alegre, RS, Brasil.Fax: +55-51-316-6045.E-mail: mtschif@vortex.ufrgs.br
}

\begin{abstract}
The work developed by the Cytogenetics Group of the Department of Forage Plants and Agrometeorology (Departamento de Plantas Forrageiras e Agrometerologia - DPFA), Agronomy Faculty, Federal University of Rio Grande do Sul (UFRGS), are reviewed in the present study. Topics discussed include: the chromosome numbers and meiotic behavior of Desmodium and Vigna; the application of cytogenetic methods (e.g., polyploidy induction in Trifolium riograndense) to plant breeding; the genetic control of chromosome pairing in autopolyploids of T. riograndense; karyotypes of the Vicia sativa aggregate in Southern Brazil as an example of a founder effect leading to a reduction in karyotype but not to morphological variability; data on the karyotypes of four Lathyrus species which show that the evolution of these species has been accompanied by a decrease in chromosome size, and the results of an investigation of variability in chromosome number in a complete genus, Leucaena. The main objectives of the group for the near future are also outlined.
\end{abstract}

\section{INTRODUCTION}

Native pastures and cytogenetics

The native pastures of Rio Grande do Sul, the southernmost Brazilian state, contain a rich diversity of native grass and legume species, many of them described as potentially good forages (Barreto and Kappel, 1964; Grossman et al., 1965). Before proceeding to agronomic evaluation and genetic breeding programs, the use of some of these taxa as forage plants adapted to regional conditions first of all requires, among other things, the gathering of basic information on their taxonomy, cytogenetics and mode of reproduction. Many of these groups may also provide interesting evolutionary case studies.

The taxonomy of many of the native grass and legume genera of Rio Grande do Sul has been elucidated by several research programs undertaken mainly by researchers at the Botany Department of UFRGS.

Regarding native grasses there is, in the university, a long tradition of cytogenetic and evolutionary research in which a great volume of data have been built up on grasses of various genera, e.g., Paspalum L. (Moraes Fernandes et al ., 1968, 1973, 1974; Hickenbick et al., 1992), Axonopus Pal. (Hickenbick et al., 1975), Briza L. (Sampaio et al., 1979;
Schifino and Winge, 1983), Setaria Beauv. (Freitas-Sacchet et al., 1984) and Sorghastrum Nash. (Flores and Valls, 1987).

The cytogenetics of native legumes started with the work of Mohrdieck (1950), who first counted the chromosomes of Trifolium riograndense, but this work was discontinued for three decades until, in the early 80 's, the cytogenetics group at Department of Forage Plants and Agrometeorology (DPFA) began to be formed.

In this study we present a review of our work on the cytogenetics of forage legumes, along with a more detailed description of some specific cases in which cytogenetic information has been linked to plant breeding and evolutionary studies.

\section{The Cytogenetics Group of the DPFA}

The objective of the first work on the cytogenetics of forage species, begun in the early 80 's, was to provide basic information for developing future breeding programs. The first studies conducted were on native or introduced grasses and legumes and included the investigation and transmission of chromosome number instability in species of Phalaris L. and its hybrids (Schifino et al., 1985, 1986; Schifino and Gus, 1986), the determination of chromosome numbers in Desmodium Desv. species (Schifino, 1983), and chromosome number confirmation in species of $\mathrm{Pas}$ palum, Hemarthria R. Br., Coelorachys Brongn. and Lolium L. (Schifino, M.T., unpublished results) that were being evaluated agronomically.

Later efforts were concentrated on legume species of immediate or future interest to plant breeding and other approaches to germplasm characterization were adopted, including isoenzyme characterization (Gonzales and Schifino-Wittmann, 1996; Schifino-Wittmann et al., 1996; Schifino-Wittmann and Lange, 1997; Lange and SchifinoWittmann, 2000), phenology and reproductive studies (Becker et al., 1987; Klamt, 1997; Tedesco et al., 1998) and, more recently, DNA markers. However, the main line is still cytogenetics. Besides the intimate link to plant breeding projects, some of the studies also allow the utilization of cytogenetical information for taxonomical delimitation as well as in evolutionary studies. The group has one permanent senior researcher and a varying number of co-workers, mainly undergraduate and graduate students. 
Recently, other authors, outside the group, have also published work on Lathyrus L. (Battistin and Fernandez, 1994; Battistin et al., 1999) and Adesmia DC. (Miotto and Forni-Martins, 1995; Coelho, 1996; Coelho and Battistin, 1998).

\section{RESULTS OF SOME SELECTED RESEARCH PROGRAMS}

\section{Desmodium, Vigna and Arachis - basic information}

Chromosome number determinations in four Desmodium species occurring in Rio Grande do Sul, D. uncinatum (Jacq.) DC. (yellow and violet-flowered bio-types), $D$. affine Schlecht., D. incanum DC. and D. triarticulatum Malme, confirmed the diploid number $(2 \mathrm{n}=22)$ for all taxa and provided an original count for $D$. triarticulatum.

Populational studies in three species of Vigna Savi, that is, V. luteola (Jacq.) Benth, V. adenantha (G.F. Meyer) Maréchal, Mascherpa \& Satainier and $V$. longifolia (Bentham) Verdcourt, showed that all species were diploid with $2 \mathrm{n}=22$, and with regular meiosis and high meiotic indexes (92-96\%) and pollen fertility (92-98\%) (Senff et al., 1992).

Senff et al. (1995) has investigated chromosome number, meiotic behavior and pollen fertility in 22 populations of Arachis pintoi Krapovicas \& Gregory $(2 \mathrm{n}=20)$, Desmodium incanum, D. uncinatum, D. triarticulatum, $D$. pachyrrizum Vog., D. cunetaum Hook et Arnt., Vigna adenantha, $V$. luteola and $V$. longifolia (all $2 \mathrm{n}=22$ ). All populations displayed regular meiosis, and meiotic indexes and pollen fertility over $96 \%$.

\section{Trifolium - cytogenetics in plant breeding and a model for chromosome pairing}

Three native Trifolium species are described for Rio Grande do Sul: T. riograndense Burkart, T. polymorphum Poir., and T. argentinense Speg. T. riograndense is very well adapted to the acid, aluminum-rich soils of Rio Grande do Sul. From the plant breeding point of view this species could be a source of acid-soil tolerance genes which could be introduced into the widely cultivated white clover ( $T$. repens L.). As was mentioned above, the first chromosome count for $T$. riograndense $(2 \mathrm{n}=16)$ was made by Mohrdieck (1950).

The cytogenetic studies with the native $T$. riograndense, T. polymorphum and T. repens were originally linked to a breeding project aimed at inducing polyploidy in T. riograndense with the subsequent crossing of the artificial autopolyploid with the exotic natural polyploid $T$. repens $(2 \mathrm{n}=32)$ in order to produce hybrids which combined the high yield of $T$. repens with the acid-soil tolerance of T. riograndense (Becker et al., 1986; Schifino and Moraes-Fernandes, 1987a; Souza et al., 1988).
Karyotypic as well as population studies of chromosome numbers and meiotic behavior were performed not only in $T$. riograndense (Figure 1a and b) but also in $T$. polymorphum (Figure 1c). The results showed that all the populations studied were formed only of diploid $(2 n=16)$ individuals, the karyotypes of both species being very similar, differing only in the position of the satellited pair. Very little intraspecific variability was observed.

Meiosis in T. riograndense was regular and meiotic indexes and pollen fertility were high. In T. polymorphum, however, about $50 \%$ of the individuals examined presented quadrivalents, trivalents and univalents in metaphase one and varying pollen fertility, unusual for a diploid inbreeding species (Schifino and Moraes-Fernandes, 1988).

Due to the smaller than expected number of quadrivalents in the autotetraploids, the comparison of diploids and induced autotetraploids of T. riograndense (Schifino and Moraes-Fernandes, 1986, 1987a) led to the suggestion that there exists a genetic control mechanism for bivalent formation in this species (Schifino and MoraesFernandes, 1987b).

\section{Vicia - a founder effect leading to a bottleneck in karyotype variability}

Seven native Vicia species and two Vicia varieties have been described for southern Brazil (Bastos and Miotto, 1996); V. sativa L. sensu str. is cultivated in backyards and fields while $V$. angustifolia L. (=V. sativa subsp. nigra), a highly polymorphic and morphologically variable naturalized ruderal, is very common in disturbed habitats (Miotto, S., personal communication).

A preliminary cytogenetic investigation of native, exotic and naturalized Vicia species (Schifino-Wittmann et al., 1994) showed all species to be diploid: the native $V$. epetiolaris Burk. (syn V. graminea Sm.), V. linearifolia Hook. et Arn., V. macrograminea Burk. (syn. V. stenophylla Vog.) and $V$. nana Vog. with $2 \mathrm{n}=14$; the exotic $V$. faba L., $V$. sativa $\mathrm{L}$. and $V$. panonica $\mathrm{L}$. with $2 \mathrm{n}=12$, and $V$. villosa Roth and $V$. hirsuta $(L$.) S.F. Gray with $2 \mathrm{n}=14$. Interesting results were found in the naturalized $V$. angustifolia, with most plants having $2 \mathrm{n}=12$ but some $2 \mathrm{n}=14$ plants were detected. Meiosis was regular in all species and meiotic indexes and pollen fertility just over $90 \%$.

More comprehensive work has been carried out with populations of the $V$. sativa aggregate in Rio Grande do Sul (Weber and Schifino-Wittmann, 1999). There are several references in the literature to the so-called Vicia sativa aggregate in the Old World. This aggregate of taxa is morphologically, karyologically and ecologically variable (Hanelt and Mettin, 1989) and its formation could be explained by the hybridization which commonly occurs in the genus (Yamamoto, 1986) and the anthropogenic disturbance of primary habitats (Zohary and Plitmann, 1979). Maxted $(1993,1995)$ recognizes one species, $V$. sativa 

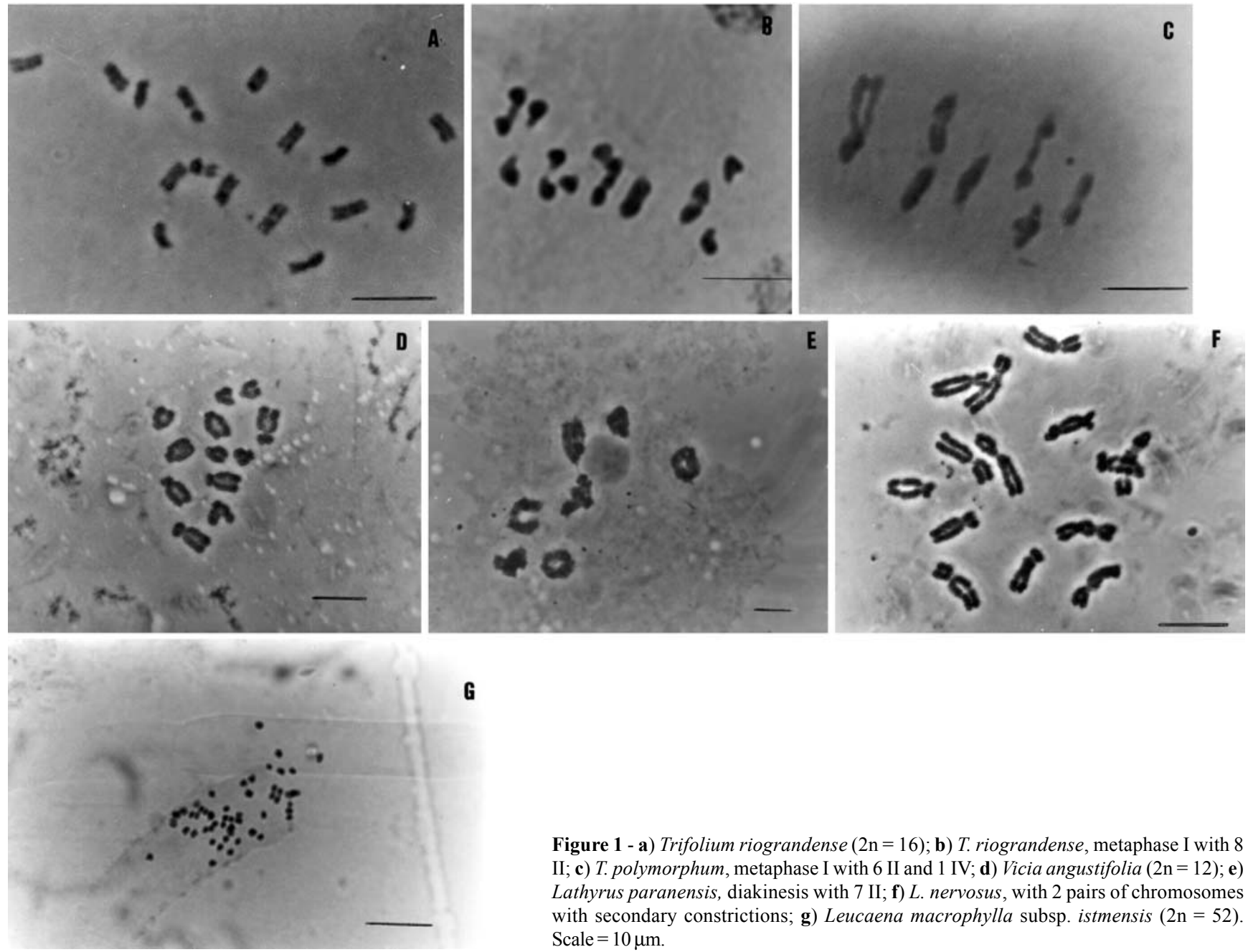

Figure 1 - a) Trifolium riograndense $(2 \mathrm{n}=16)$; b) T. riograndense, metaphase I with 8 II; c) T. polymorphum, metaphase I with 6 II and 1 IV; d) Vicia angustifolia $(2 \mathrm{n}=12)$; e) Lathyrus paranensis, diakinesis with $7 \mathrm{II}$; f) L. nervosus, with 2 pairs of chromosomes with secondary constrictions; g) Leucaena macrophylla subsp. istmensis $(2 \mathrm{n}=52)$. Scale $=10 \mu \mathrm{m}$.

L., and six subspecies, while Potokina (1997) recognizes seven separate species. The different forms coexist sympatrically, and present high morphological and karyotypical variability (Hollings and Stace, 1974; Ladizinsky, 1978, 1981; Ladizinsky and Temkim, 1978; Zohary and Plitmann, 1979; Ladizinsky and Shefer, 1982; Hanelt and Mettin, 1989). The taxa are reproductively compatible and the hybrids partially fertile (Ladizinsky, 1978). It is known that the still cultivated $V$. sativa was brought to Rio Grande do Sul by Italian settlers during the XIX century and it is thought that $V$. angustifolia probably came along with it as a weed, since both taxa are very similar and difficult to separate during harvest. $V$. angustifolia expanded around the areas of $V$. sativa cultivation and became a widespread ruderal in the state.

The investigation of the karyotypes of taxa of the Vicia sativa aggregate in southern Brazil (Weber and SchifinoWittmann, 1999) provides an example of a founder effect, which although not leading to loss of morphological variability did produce a reduction in karyotype variability. The analyses of 37 accessions of $V$. sativa, $V$. angustifolia, intermediate types, and $V$. cordata Wulf. ex. Hoppe from the
States of Rio Grande do Sul and Santa Catarina allowed the separation of three taxa according to their karyotypes (Figure 2). V. sativa had $2 \mathrm{n}=12$ with five acrocentric chromosome pairs, one with a secondary constriction in the long arm and one marker metacentric chromosome pair. $V$. cordata had $2 \mathrm{n}=10$ acrocentric chromosomes, and the smalest pair had a secondary constriction in the long arm. All accessions of $V$. angustifolia had $2 \mathrm{n}=12$ acrocentric chromosomes, one with a secondary constriction in the long arm (Figure 1d). Schifino-Wittmann et al. (1994) had previously described $V$. angustifolia from Rio Grande do Sul as having $2 \mathrm{n}=14$ but this chromosome number was not found in the accessions included in the study described in the present paper, where the karyotypic data $(2 n=12)$ agrees with what was found by Hanelt and Mettin (1966) and Ladizinsky (1978).

These results show a relation between karyotype and taxonomy, the presence of a marker metacentric chromosome in $V$. sativa providing a clear-cut distinction between the taxa. Despite the sympatry of different taxa of the $V$. sativa aggregate in southern Brazil, no mixed or different cytotypes were found. One possible explanation for this is 


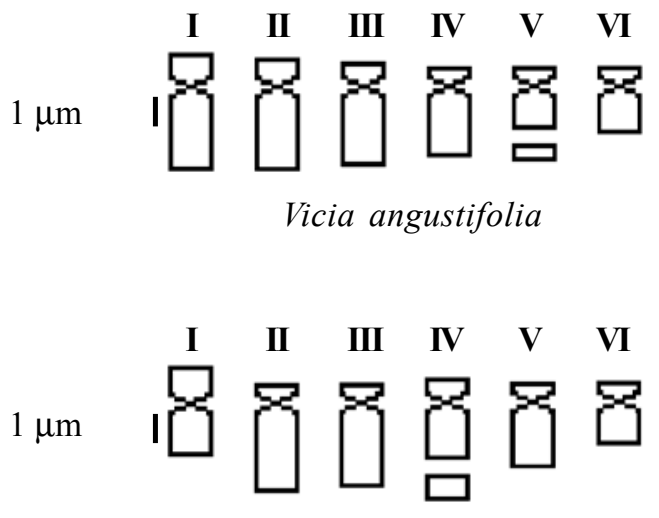

Vicia sativa

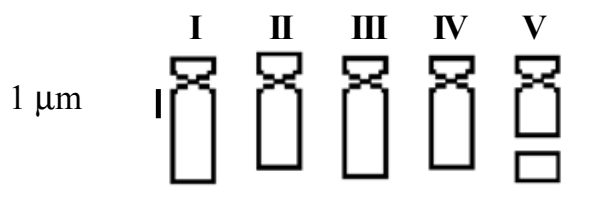

Vicia cordata

Figure 2 - Idiograms of the Vicia sativa aggregate taxa (from Weber and Schifino-Wittmann, 1999).

some type of "founder effect", where the introduced $V$. sativa were probably stable cultivated forms while $V$. angustifolia seeds that came as weeds with these introductions, having been collected in the same localities, did not contain wide karyotypic variation.

\section{Lathyrus - an evolutionary trend in chromosome size decrease}

The 23 Lathyrus species endemic to South America were included in the section Notholathyrus by Kupicha (1983). Of these, 12 (L. crassipes Gill ap. Hook. et Arn., L. hasslerianus Burk., L. hookeri G. Don., L. linearifolius Vog., L. macrostachys Vog., L. nervosus Lam., L. nitens Vog., L. paranensis Burk., L. paraguariensis Hass., L. parodii Burk., L. pubescens Hook. et Arn., and L. subulatus Lam.) occur in Rio Grande do Sul (Neubert, E., personal communication).

Chromosome number and meiotic behavior were studied in the native species L. crassipes (syn. L. pusillus), $L$. subulatus, L. paranensis (Figure 1e), L. pubescens, $L$. nervosus, L. sp. (later defined as L. linearifolius), and in the exotics L. sativus L. and L. latifolius L. Meiotic behavior was normal, and meiotic indexes and pollen fertility were generally over $90 \%$. All species were diploid, with $2 n=14$ chromosomes (Schifino-Wittmann et al., 1994). This agrees with previous studies of Lathyrus species, including South American taxa (Federov, 1969; Kupicha, 1983; Yamamoto et al., 1984; Broich, 1989; Battistin and Fernandez, 1994).
Polyploidy is uncommon in the genus (Federov, 1969) and all known species in the section Notholathyrus are diploid.

The karyotypes of 38 accessions of $L$. nervosus, $L$. pubescens, $L$. paranensis and L. crassipes have been analyzed (Klamt, 1997; Klamt and Schifino-Wittmann, 2000), the karyotypic formulae being $2 \mathrm{~m}+12 \mathrm{sm}$ for $L$. nervosus, $L$. pubescens and $L$. paranensis and $4 \mathrm{~m}+10 \mathrm{sm}$ for $L$. crassipes. In all these species the smallest chromosome pair bore a secondary constriction with a satellite in the long arm. Intraspecific variability in the position and number of secondary constrictions was observed in L. nervosus (Figure 1f) and L. pubescens. All of the species had a conservative karyotype morphology but differed in total complement size by as much as $20 \%$ between the highest (L. nervosus, 43.6 $\mu \mathrm{m})$ and the lowest (L. crassipes, $35.54 \mu \mathrm{m})$ values. There was symmetrical variation in the size of the chromosomes in the different species suggesting that changes in chromosome size during evolution have been homogeneous along the complement. Equal amounts of DNA had been lost (or acquired) by all the chromosomes as suggested by Narayan and Durrant (1983) for some Lathyrus species.

Total chromosome length in perennial Lathyrus species is generally greater than for annual species (Rees and Hazarika, 1969; Yamamoto et al., 1984). L. nervosus and $L$. pubescens are outbreeding perennials, $L$. crassipes an inbreeding annual, and L. paranensis an annual (Burkart, 1935, 1987). Generally annual species are derived from perennial species and inbreeding species from outbreeding species. Our data suggest that the evolution of the Lathyrus species studied was accompanied by a decrease in chromosome size and that L. crassipes is a derived species. This interpretation is based on the total chromosome complement length, life cycle and mode of reproduction of the four species examined.

\section{Leucaena}

The Central American genus Leucaena Benth (Leguminosae) is one of the most well known and widespread genera of nitrogen-fixing multipurpose trees. Nowadays two species, $L$. leucocephala (Lam.) de Wit. and $L$. diversifolia (Schltdl.) Benth., are widely grown in the tropical regions of the world where they have great economic and social importance (Hughes, 1993). Leucaena taxonomy has been a controversial subject for many years until the comprehensive and complete work of Hughes (1998a and b), recognizing 22 species, 4 subspecies, 2 varieties and 2 named hybrid taxa. The evolution of the genus is complex, possibly involving speciation by reticulate evolution. It has been suggested that $L$. leucocephala may have arisen as a result of indigenous domestication (Hughes and Harris, 1995; Harris et al., 1996). If adapted plants are selected, there is great potential for Leucaena utilization in Rio Grande do Sul as forage, as a dietary supplement or as a protein bank, and this explains the interest of our group in this genus. 
Hybrids

Studies in L. leucocephala $(2 \mathrm{n}=4 \mathrm{x}=104), L$. trichandra (Zucc.) Urban $(2 \mathrm{n}=2 \mathrm{x}=52$, formerly known as L. diversifolia subsp. stenocarpa) and their F1, F2 and F3 hybrids, selected for tolerance to acid soils, showed a variation from diploid to tetraploid numbers and a tendency to high chromosome numbers in advanced generations (Freitas et al., 1988). Hybrids between L. leucocephala and $L$. diversifolia, both $2 \mathrm{n}=4 \mathrm{x}=104$, were all $2 \mathrm{n}=104$ with regular meiosis and high pollen fertility (Freitas et al., 1991a,b). Unreduced gametes were observed in these crosses, up to $30 \%$ in some individuals (Schifino-Wittmann et a1., 1997; Schifino-Wittmann and Simioni, 1998).

\section{Chromosome number determinations in the whole genus}

There is still a gap in the cytogenetic data of this genus since most of the available information is restricted to chromosome counts of a few plants per species and meiotic studies in some species and hybrid populations (Gonzales et a 1., 1967; Pan and Brewbaker, 1988; Palomino et $a l ., 1995)$ and also because many of the chromosome counts are imprecise or not confirmed (Hughes, 1998), with even the chromosome number unknown for some species. The main reasons for this scarcity of information include small chromosome size (about $1 \mu \mathrm{m}$ ), the high number of chromosomes $(2 \mathrm{n}=52,56,104$ and 112, according to the literature), which makes chromosome counting difficult, and the lack, until recently, of a defined taxonomy. To fill the gaps in the cytogenetic information available for the genus our group, in collaboration with the Oxford Forestry Institute (OFI - University of Oxford, UK), is developing a program of cytological analysis based on the OFI germplasm collection of the genus.

Somatic chromosome counts in 51 provenances (Schifino-Wittmann et al., 1999 and in press) gave chromosome numbers of $2 \mathrm{n}=52$ for $L$. esculenta (Sesse \& Moc. ex DC.) Benth., L. lanceolata S. Watson var. lanceolata and var. sousae (S. Zárate) C.E. Hughes, L. magnifica (C.E. Hughes) C.E. Hughes, L. pueblana Britton \& Rose and $L$. shanonii J.D. Smith, $2 \mathrm{n}=56$ for $L$. collinsii Britton $\&$ Rose subsp. zacapana C.E. Hughes, L. greggii S. Watson and $L$. matudae (S. Zarate) C.E. Hughes, $2 \mathrm{n}=104$ for $L$. confertiflora $\mathrm{S}$. Zarate var. confertiflora, $L$. diversifolia, L. leucocephala subsp. leucocephala and subsp. glabrata (Rose) S. Zarate and L $x$ spontanea, and $2 \mathrm{n}=112$ for $L$. involucrata $\mathrm{S}$. Zarate, therefore increasing the number of known tetraploid species in the genus. Intrataxon variability was found in L. macrophylla Benth. subsp. istmensis C.E. Hughes (Figure $1 \mathrm{~g})(2 \mathrm{n}=52$ and 56), L. confertiflora var. adenotheloidea (S. Zarate) C.E. Hughes $(2 n=104$ and 112), L. pallida Britton \& Rose $(2 \mathrm{n}=104$ and 112$)$ and $L$. trichandra $(2 \mathrm{n}=52$ and 104). These results support the theory of complex evolutionary patterns in the genus and the multiple origins of tetraploid $L$. confertiflora and $L$. pallida. Most of the 25 provenances analyzed had pollen fertility of over $90 \%$. A varying percentage of unreduced gametes was found, up to $12 \%$ in the diploid $L$. trichandra $3 / 91$, opening the possibility of utilizing unreduced gametes in genetic breeding of the genus.

\section{PERSPECTIVES}

The cytogenetic study of the genus Leucaena is still going on, including a thorough meiotic analysis of all taxa in the OFI collection.

Regarding native legumes, a detailed meiotic analysis of about 90 accessions of the 17 Brazilian species of Adesmia is currently being developed as well as chromosome number determination for those taxa for which this information is lacking, and this work will be repeated with the genus Lupinus L.

A comprehensive project on the occurrence of unreduced gametes in native and cultivated forage legumes is underway due to its importance in plant breeding programs.

\section{REFERENCES}

Barreto, I.L. and Kappel, A. (1964). Principais espécies de gramíneas e leguminosas das pastagens naturais do Rio Grande do Sul. Anais do XV Congresso da Sociedade Botânica do Brasil, pp. 281-294.

Bastos, N.R. and Miotto, S.T.S. (1996). O gênero Vicia L. (LeguminosaeFaboideae) no Brasil. Pesquisas (ser. Botânica) 46: 85-180.

Battistin, A. and Fernandez, A. (1994). Karyotypes of four species of South America natives and one cultivated species of Lathyrus L. Caryologia 47: 325-330.

Battistin, A., Biondo, E. and Coelho, L.G. M. (1999). Chromosomal characterization of three native and one cultivated species of Lathyrus L. in Southern Brazil. Genet. Mol. Biol. 22: 557-563.

Becker, L.C.M., Schifino-Wittmann, M.T., Paim, N.R. and Riboldi, J. (1986). Induction of polyploidy and agronomic comparison of diploid and tetraploid forms of Trifolium riograndense Burkart. Rev. Bras. Genet. IX: 645- 657.

Becker, L.C.M., Schifino-Wittmann, M.T., Paim, N.R. and Riboldi, J. (1987). Observations on the mode of reproduction of Trifolium riograndense Burkart (Leguminosae). Ciên. Cult. 39: 304-306.

Broich, S.L. (1989). Chromosome number of North American Lathyrus (Fabaceae). Maldrono, 36: 41-48.

Burkart, A. (1935). Revision de las especies de Lathyrus de la Republica Argentina. Rev. Fac. Agron. Vet. B. Aires, 8: 41-128.

Burkart, A. (1987). Flora Ilustrada de Entre Rios. Coleccion Cientifica del INTA, VI, INTA, Buenos Aires.

Coelho, L.G.M. (1996). Citogenética e qualidade Forragem de espécies de Adesmia DC. nativas no Rio Grande do Sul. Master's thesis, Santa Maria, RS.

Coelho, L.G. and Battistin, A. (1998). Meiotic behavior of Adesmia DC. (Leguminosae-Faboideae) species native to Rio Grande do Sul, Brazil. Genet. Mol. Biol. 21: 404-406.

Federov, A.A. (1969). Chromosome Numbers of Flowering Plants. Academy of Science of the URSS, Leningrad.

Flores, A.I.P. and Valls, J.F.M. (1987). Aspectos citológicos (número cromossômico, regularidade meiótica e viabilidade do grão de pólen) em espécies do gênero Sorghastrum Nash (Gramineae; Andropogoneae). Iheringia 36: 1-82.

Freitas, L.H.C., Schifino-Wittmann, M.T. and Hutton, E.M. (1988). Cytogenetic analysis of species and hybrids of Leucaena (Leguminosae) in relation to acid soil tolerance. Rev. Bras. Genet. 11: 97-109.

Freitas, L.H.C., Schifino-Wittmann, M.T. and Paim, N.R. (1991a). Floral 
characteristics, chromosome number and meiotic behavior of hybrids between Leucaena leucocephala $(2 \mathrm{n}=104)$ and tetraploid $L$. diversifolia $(2 \mathrm{n}=104)$. Rev. Bras. Genet. 14: 781-789.

Freitas, L.H.C., Paim, N.R. and Schifino-Wittmann, M.T. (1991b). Morphological characterization and cytogenetical analysis of Leucaena leucocephala $\mathrm{x}$ tetraploid $L$. diversifolia hybrids. Leucaena Res. Rep. 12: 16-18.

Freitas-Sacchet, A.M.O., Boldrini, I.I. and Born, G.G. (1984). Cytogenetics and evolution of the native grasses of Rio Grande do Sul, Brazil Setaria Beauv. (Gramineae). Rev. Bras. Genet. VII: 535-548.

Gonzalez, V., Brewbaker, J.L. and Hamil, D.E. (1967). Leucaena cytogenetics in relation to the breeding of low mimosine lines. Crop Sci. 7: 140-143.

Gonzalez, A.C. and Schifino-Wittmann, M.T. (1996). Isoenzymatic characterisation of some Lathyrus L. and Vicia L. species (Leguminosae) occurring in Rio Grande do Sul (Southern Brazil). Braz. J. Genet.19: 283-288.

Grossman, J., Aronovich, S. and Campello, E.C.B. (1965). Grasslands of Brazil. Proceedings of the IX International Grassland Congress, pp. $39-47$

Hanelt, P. and Mettin, D. (1966). Cytosystematische Untersuchungenin der Artengruppe Vicia sativa L. II. Kulturpflanze 14: 137-161.

Hanelt, P. and Mettin, D. (1989). Biosystematics of the genus Vicia L. (Leguminosae). Ann. Rev. Ecol. Syst. 20: 199-223.

Harris, S.A., Chamberlain, J.R. and Hughes, C.E. (1996). New insights into the evolution of Leucaena Benth. In: Advances in Legume Systematics. Part 8. Legumes of Economic Importance (Pickersgill, B. and Lock, J.M., eds.). Royal Botanical Gardens, Kew, pp. 117-126.

Hickenbick, M.C.M., Valls, J.F.M., Salzano, F.M. and Moraes-Fernandes, M.I.B. (1975). Cytogenetic and evolutionary relationships in the genus Axonopus (Gramineae). Cytologia 40: 185-204.

Hickenbick, M.C.M., Flores, A.I.P., Cavalli-Molina, S., Weber, L.H., Kersting, A.C.O., Costa, L.S., Souza-Chies, T.T. and Albarus, M.H. (1992). Mode of reproduction and seed production in Paspalum dilatatum Poir Virasoro biotype - Dilatata group (Gramineae). Rev. Bras. Genet. 15: 85-102.

Hollings, E. and Stace, C.A. (1974). Karyotype variation and evolution in the Vicia sativa aggregate. New Phytol. 73: 195-208.

Hughes, C.E. (1993). Leucaena Genetic Resources: The OFI Seed Collections and a Synopsis of Species Characteristics. Oxford Forestry Institute, Oxford.

Hughes, C.E. (1998a). Handbook of Leucaena Genetic Resources. Oxford Forestry Institute, Oxford.

Hughes, C.E. (1998b). Monograph of Leucaena Benth. (Leguminosae: Mimosoideae). Systematic Botany Monographs 55. The American Society of Plant Taxonomists, Ann Harbor.

Hughes, C.E. and Harris, S.A. (1995). Systematics of Leucaena: recent findings and applications for breeding and conservation. In: Leucaena: Opportunities and Limitations (Shelton, H.M., Piggin, C.M. and Brewbaker, J.L, eds.). ACIAR, Canberra. Proceedings 57: 54-65.

Klamt, A. (1997). Caracterização de algumas espécies do gênero Lathyrus do Rio Grande do Sul: fenologia e cariótipos. Master's thesis, Universidade Federal do Rio Grande do Sul, Porto Alegre.

Klamt, A. and Schifino-Wittmann, M.T. (2000). Karyotype morphology and evolution in some Lathyrus species of Southern Brazil. Genet. Mol. Biol. 23: 463-467.

Kupicha, F.K. (1983). The infrageneric structure of Lathyrus. Royal Bot. Gard. Edinb. 41: 209-244.

Ladizinsky, G. (1978). Chromosomal polymorphism in wild populations of Vicia sativa L. Caryologia 31: 233-241.

Ladizinsky, G. (1981). Consequences of hybridization in Vicia sativa aggregate. Heredity 47: 431-438

Ladizinsky, G. and Shefer, Y. (1982). Polyploidy in the Vicia sativa aggregate. New Phytol. 91: 541-547.

Ladizinsky, G. and Temkim, R. (1978). The cytogenetic structure of Vicia sativa aggregate. Theor. Appl. Genet. 53: 33-42.

Lange, O. and Schifino-Wittmann, M.T. (2000). Isozyme variation in wild and cultivated species of the genus Trifolium L. (Leguminosae). Ann. Bot. 86: 339-345.

Maxted, N. (1993). A phenetic investigation of Vicia L. subgenus Vicia (Leguminosae-Vicieae). Bot. J. Linn. Soc. 111: 155-182.
Maxted, N. (1995). An ecogeographical study of Vicia subgenus Vicia. Systematic and Ecogeographic Studies on Crop Genepools. 8. IPGRI, Rome.

Miotto, S.T.S. and Forni-Martins, E.R. (1995). Número cromossômico em espécies brasileiras de Adesmia DC. (Leguminosae- Faboideae). Acta Bot. Bras. 8: 3-9.

Mohrdieck, K.H. (1950). Observações sobre o número de cromosomas no Trifolium riograndense Burkart. Rev. Agron. 14: 210-214.

Moraes Fernandes, M.I.B., Barreto, I.L. and Salzano, F.M. (1968). Cytogenetic, ecologic and morphologic studies in Brazilian forms of Paspalum dilatatum. Can. J. Genet. Cytol. 10: 131-138.

Moraes Fernandes, M.I.B., Barreto, I.L. and Salzano, F.M. (1973). Cytogenetic, ecologic and morphologic studies in Brazilian forms of Paspalum notatum. Can. J. Genet. Cytol. 15: 523-531.

Moraes Fernandes, M.I.B., Barreto, I.L., Salzano, F.M. and Sacchet, A.M.O.F. (1974). Cytological and evolutionary relationships in Brazilian forms of Paspalum (Gramineae). Caryologia 27: 455-465.

Narayan, R.K.J. and Durrant, A. (1983). DNA distribution in chromosomes of Lathyrus species. Genetica 61: 47-53.

Palomino, G., Romo, G. and Zárate, S. (1995). Chromosome numbers and DNA content in some taxa of Leucaena (Fabaceae: Mimosoideae). Cytologia 60: 31-37.

Pan, F.J. and Brewbaker, J.L. (1988). Cytological studies in the genus Leucaena Benth. Cytologia 53: 393-399.

Potokina, E.K. (1997). Vicia sativa L. aggregate (Fabaceae) in the flora of former USSR. Genet. Res. Crop. Evol. 44: 199-209.

Rees, H. and Hazarika, M.H. (1969). Chromosome evolution in Lathyrus. Chromosomes Today 2: 158-165.

Sampaio, M.T.S., Hickenbick, M.C.M. and Winge, H. (1979). Chromosome numbers and meiotic behavior of South American species of the Briza complex (Gramineae). Rev. Bras. Genet. II: 125-134.

Schifino, M.T. (1983). Chromosome numbers and meiotic behavior in five native Brazilian forage legume species. Rev. Bras. Genet. VI: 357-362.

Schifino, M.T. and Gus, R. (1986). Transmission of somatic chromosome number instability in Phalaris L. (Gramineae). Rev. Bras. Genet. IX: 549-554.

Schifino, M.T. and Moraes-Fernandes, M.I.B. (1986). Cytological comparison of diploid and autotetraploid Trifolium riograndense Burkart. Rev. Bras. Genet. IX: 637-643.

Schifino, M.T. and Moraes-Fernandes, M.I.B. (1987a). Induction of polyploidy and cytological characterization of autotetraploids of Trifolium riograndense Burkart (Leguminosae). Euphytica 36: 863-872.

Schifino, M.T. and Moraes-Fernandes, M.I.B. (1987b). Cytological evidence of genetic control of chromosome pairing in artificial autotetraploids of Trifolium riograndense Burkart. Genetica 74: 225-230.

Schifino, M.T. and Moraes-Fernandes, M.I.B. (1988). Chromosome numbers, karyotypes and meiotic behavior of populations of some Trifolium (Leguminosae) species. Rev. Bras. Genet.11: 637-643.

Schifino, M.T. and Winge, H. (1983). Karyotypes and nuclear DNA content of species of the Briza complex and some other genera of Poeae (Gramineae). Rev. Bras. Genet. VI: 245-259.

Schifino, M.T., Zanella, C.C. and Gus, R. (1985). Chromosome number instability in Phalaris L. Cytologia 50: 89-99.

Schifino-Wittmann, M.T. and Lange, O. (1997). Isoenzymatic characterization of native and cultivated forage legume species of Rio Grande do Sul (Southern Brazil). Proceedings of the XVIII International Grassland Congress, Winniperg, 1997, pp. 1-47-48.

Schifino-Wittmann, M.T. and Simioni, C. (1998). More about unreduced gametes in Leucaena. Leucnet News 5: 21-22.

Schifino-Wittmann, M.T., Lau, A.H.L. and Simioni, C. (1994). The genera Vicia and Lathyrus (Leguminosae) in Rio Grande do Sul (Southern Brazil): cytogenetics of native, naturalized and exotic species. Rev. Bras. Genet. 17: 313-319.

Schifino-Wittmann, M.T., Freitas, L.H.C. and Simioni, C. (1996). Isoenzymatic characterization of hybrids between Leucaena leucocephala and Leucaena diversifolia ssp. diversifolia grown in Rio Grande do Sul (Southern Brazil). Braz. J. Genet. 19: 475-478.

Schifino-Wittmann, M.T., Freitas, L.H.C., Simioni, C. and Paim, N.R. (1997). Unreduced gametes in Leucaena. Leucnet News 4: 28-29.

Schifino-Wittmann, M.T., Cardoso, M.B. and Boff, T. (1999). Chromosome numbers of Leucaena species: filling the gaps and discovering 
a new tetraploid species. Leucnet News 6: 10-12.

Schifino-Wittmann, M.T., Cardoso, M., Boff, T. and Simioni, C. (2001)

Chromosome numbers and unreduced gametes in species of Leucaena Benth (Leguminosae) - new contributions for the taxonomy, evolutionary studies and genetic breeding of the genus. Forest Genet. (in press).

Senff, M.I., Hickenbick, M.C.M. and Paim, N.R. (1992). Cytogenetic studies in species of the genus Vigna Savi (Leguminosae-Papilionoideae). Braz. J. Genet. 15: 407-418.

Senff, M.I., Schifino-Wittmann, M.T. and Paim, N.R. (1995). Cytogenetic studies of populations of Arachis, Desmodium and Vigna species (Leguminosae, Papilionoideae) from Rio Grande do Sul. Rev. Bras. Genet. 18: 629-631.

Souza, E.H. de, Paim, N.R., Schifino, M.T. and Riboldi, J. (1988). Caracterização morfológica e fisiológica das formas diplóide e tetraplóide de Trifolium riograndense em comparação com Trifolium re- pens e Trifolium polymorphum. Pesqui. Agropecu. Bras. 23: 599607.

Tedesco, S.B., Dall'Agnol, M. and Schifino-Wittmann, M.T. (1998). Observações sobre o modo de reprodução de Adesmia latifolia Spreng. Vog. Santa Maria: Ciênc. Rural 1: 141-142.

Weber, L.H. and Schifino-Wittmann, M.T. (1999). The Vicia sativa L. aggregate (Fabaceae) in Southern Brazil. Gen. Res. Crop Evol. 46: $207-$ 211.

Yamamoto, K., Fujiware, T. and Blumenreich, I.D. (1984). Karyotypes and morphological characteristics of some species in the genus Lathyrus L. Jpn. J. Breed. 34: 273-284.

Yamamoto, K. (1986). Interspecific hybridization among Vicia narbonensis and its related species. Biol. Zbl. 105: 181-197.

Zohary, D. and Plitmann, U. (1979). Chromosome polymorphism, hybridization and colonization in the Vicia sativa group (Fabaceae). Plant Syst. Evol. 131: 143-156. 
